\title{
Effect of poly ( $\gamma$-glutamic acid) on wheat productivity, nitrogen use efficiency and soil microbes
}

\author{
Z. Xu ${ }^{1}$, Ch. Wan ${ }^{1}, X . X u^{2}, X . F^{1}, H . X u^{1 *}$ \\ ${ }^{1}$ State Key Laboratory of Materials-Oriented Chemical Engineering, College of Food Science and Light Industry, Nanjing \\ University of Technology, Nanjing 211816, PR China. ${ }^{2}$ Institute of Agricultural Resource and Environmental Sciences, Jiangsu \\ Academy of Agricultural Sciences, Nanjing 210014, PR China. *Corresponding author: xuh@njut.edu.cn
}

\begin{abstract}
Recently, with numerous environmental problems being caused by chemical fertilizer overuse, agricultural practices are shifting toward the development of environmentally friendly $\mathrm{N}$ fertilizers. In this study, pot and field experiments were simultaneously conducted to investigate the effect of poly ( $\gamma$-glutamic acid) ( $\gamma$-PGA) on the yield, $\mathrm{N}$ use efficiency, and soil microenvironment of wheat. Our study demonstrates a statistically significant increase in winter wheat, number of tillers, seed number per spike, yield, soil microbial biomass N (SMBN), and soil enzymes after $\gamma$-PGA application. The highest grain yield of $7435.69 \pm 55.91 \mathrm{~kg} \mathrm{ha}^{-1}$ was obtained after $\gamma$-PGA application in the field experiment, which was $7.17 \%$ higher than the urea control. The $\mathrm{N}$ recovery efficiency increased by $11.81 \%-14.00 \%$ and $11.30 \%-11.38 \%$ after the application of $\gamma$-PGA in pot and field experiments, respectively. More mineral nitrogen in soil was immobilized by the microbes after $\gamma$-PGA application at the early growth stage of wheat. The immobilized nitrogen was gradually released at the late growth stage. The results demonstrate that $\gamma$-PGA can be used as a fertilizer synergist.
\end{abstract}

Keywords: Poly ( $\gamma$-glutamic acid), fertilizer synergist, $\mathrm{N}$ use efficiency, soil microbial biomass nitrogen, soil enzyme

\section{Introduction}

Modern agriculture now feeds 6 billion people in the global world. To meet the recent growing demand for food, investments on agriculture are increasing. Consequently, synthetic fertilizer application is also increasing (Thakur et al., 2013). Globally, fertilizer nitrogen $(\mathrm{N})$ application has increased rapidly over the past several decades, from 32 million tons in 1970 to around about 100 million tons in 2010; it is expected to increase to $130-150$ million tons/year by
2050 (Matson et al., 1998). However, the overuse of chemical fertilizers in farmlands is a major contributor to environmental problems such as ground water eutrophication, nitrate pollution, phosphate pollution, and others (Datta et al., 2010; Mahmoud and Abd EL-Kader, 2012). Due to increasing human health concerns and pressure in meeting stringent consumer standards, agricultural practices are shifting toward the development of nitrogen $(\mathrm{N})$ fertilizers that are 
environmentally friendly, possess high $\mathrm{N}$ utilization efficiency, and can sustain crop production. Several strategies have been proposed to reduce $\mathrm{N}$ losses, such as the use of urease and nitrification inhibitors or coated fertilizers (Bremner, 1995; Han et al., 2008; Khalil et al., 2009). However, all these fertilizer technologies have disadvantages. For example, coated fertilizer is too expensive for wide agricultural use. Several nitrification inhibitors are also not easily available and likely to be toxic to animals and other microorganisms (Iizumi et al., 1998). Therefore, an environmentally friendly fertilizer synergist is required.

Poly ( $\gamma$-glutamic acid) $(\gamma$-PGA) is a water-soluble, biodegradable biopolymer produced by microbial fermentation that consists of D- and L-glutamic acid monomers connected by amide linkages between $\alpha$-amino and $\gamma$-carboxyl groups. $\gamma$-PGA can be used in a broad range of industrial fields such as food, medicine, cosmetics, water treatment, and agriculture (Shih and Van, 2001; Ashiuchi, 2010). Given the non-toxicity, high biodegradability, and environment friendliness of $\gamma$-PGA, it is attracting interest for potential application as an environment-friendly fertilizer synergist like thermal polyaspartate (TPA) and other polyamino acids (Koskan et al., 1998; Chen et al., 2005; King et al., 2011). Winter wheat (T. aestivum $\mathrm{L}$.) is one of the most important food and feed grain crops in the world. However, wheat production requires high levels of chemical fertilizer, which often leads to nutritional imbalance in soil and declined crop productivity. Soil microbes are the living part of soil organic matter that play critical roles in soil $\mathrm{N}$ cycling as well as overall soil quality and fertility (Doran, 1987; Tu et al., 2006; Goulding, 2007; Ulrich et al., 2010). They serve as both source and sink of plant nutrients (Dalal, 1998; Yang et al., 2013). Previous studies have shown that polyaspartate can enhance plant productivity and the efficient utilization of plant growth nutrients. Wang et al. (Wang et al., 2008) found that $\gamma$-PGA can significantly increase the dry weight of both roots and shoots and the roots to shoots ratio $(\mathrm{R} / \mathrm{S})$ of the cucumber seedlings. To date, there is no report about the effects of $\gamma$-PGA on soil microbes and soil enzymes. Therefore, the relationship between $\mathrm{N}$ transformation and crop productivity after fertilizer synergist addition must be determined. In the present study, the effects of $\gamma$-PGA on wheat productivity and soil microbes were evaluated.

\section{Materials and Methods}

\subsection{Pot experiment}

A pot experiment was conducted in a greenhouse in the Institute of Agricultural Resource and Environmental Sciences at Jiangsu Academy of Agricultural Sciences

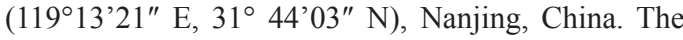
experiment lasted from November 24, 2010 to May 15,2011 . The greenhouse utilized natural light. The soil was air-dried, ground and sieved through a $2 \mathrm{~mm}$ sieve. The characteristics of the experimental soil were as follows: $\mathrm{pH} 6.27$ (1:5 soil-water ratio), organic matter of $13.70 \mathrm{~g} \mathrm{~kg}^{-1}$ soil, alkaline hydrolysis $\mathrm{N}$ of $104.72 \mathrm{mg} \mathrm{kg}^{-1}$ soil, Olsen-P of $22.30 \mathrm{mg} \mathrm{kg}^{-1}$ soil, and available $\mathrm{K}$ of $97.47 \mathrm{mg} \mathrm{kg}^{-1}$ soil.

\subsection{Experimental design of pot experiment}

The pot experiment consisted of six different treatments involving $\gamma$-PGA. The fertilizer treatments were as follows: no urea control (control, na), urea (nb), PGAU1 (nc), PGAU2 (nd), PGAU1 with a reduction of $15 \%$ nitrogen contene, and PGAU2 with a reduction of $15 \%$ nitrogen content (nf). PGAU1 was urea mixed with purified $\gamma$-PGA. PGAU2 was urea coated with purified $\gamma$-PGA. The addition level of $\gamma$-PGA in PGAU1 and PGAU2 were both $0.10 \%$. Turn on the blower power of the coating machine and then adjust the heating power to $400 \mathrm{~W}$. The coating agent concentration of $\gamma$-PGA is $20 \mathrm{gL}^{-1}$ and the rotate speed of coating machine is $30 \mathrm{r} \mathrm{min}^{-1} .2 \mathrm{~kg}$ of urea was coated with $100 \mathrm{ml}$ of $\gamma$-PGA by BY-400 coating machine. After coating the coated urea was stored in a desiccator for use. Seed were sown in s of winter wheat (Triticum aestivum L. cv. Ningmai 13) were sown in 
plastic pots $(21.00 \mathrm{~cm}$ diameter $\times 23.00 \mathrm{~cm}$ height $)$ filled with $2.50 \mathrm{~kg}$ of sieved air-dried topsoil. Eleven seeds per pot were planted and later thinned to five plants. The experiment was arranged in a completely randomized design with four replicates. All pots were randomized weekly during the experiment. Urea, as the $\mathrm{N}$ fertilizer, was added to each pot at the rate of $150.00 \mathrm{mg} \mathrm{N}$ per kilogram soil before sowing stage. Superphosphate and potassium sulfate were applied in each treatment at the rates of $100.00 \mathrm{mg} \mathrm{P}_{2} \mathrm{O}_{5}$ and $150.00 \mathrm{mg} \mathrm{kg}^{-1} \mathrm{~K}_{2} \mathrm{O}$ soil, respectively, before sowing. All chemical regents used were analytical grade. Deionized water was used throughout the experiment.

\subsection{Soil, plant sampling and analysis in pot experiment}

At the tillering, jointing, booting, and maturity stages, the plants in each pot were harvested at ground level. The total $\mathrm{N}$ content of each sample was determined using the Kjeldahl method on a whole wheat flour sample prepared using a disc mill $(0.20 \mathrm{~mm}$ setting $)$. Total protein concentration was estimated as $\mathrm{N} \times$ 5.70. Apparent $\mathrm{N}$ recovery efficiency was calculated using 'difference method' following Motavalli et al. (Motavalli et al., 1989) as below:

Apparent $\mathrm{N}$ recovery $(\%)=[(\mathrm{N}$ accumulation in treatment $-\mathrm{N}$ accumulation in control)/total $\mathrm{N}$ applied] x $100 \%$.

Each soil sample was separated into two parts. One part was air dried and sieved through a $2.00 \mathrm{~mm}$ sieve for physical and chemical analyses, and the other part was passed through a $2.00 \mathrm{~mm}$ sieve and frozen until biochemical analysis. To determine their ammonium $\mathrm{N}\left(\mathrm{NH}_{4}^{+}-\mathrm{N}\right)$ and nitrate $\mathrm{N}\left(\mathrm{NO}_{3}^{-}-\mathrm{N}\right)$ contents, $10.00 \mathrm{~g}$ of fresh soil was extracted with $50.00 \mathrm{ml}$ of $2.00 \mathrm{M}$ $\mathrm{KCl}$ by shaking for $1 \mathrm{~h}$. Filtered soil extracts were analyzed using a Lachart Flow Injection Analyzer (Henriksen and Selmer-Olsen, 1970; Krom, 1980). Soil microbial biomass N (SMBN) was determined by the chloroform-fumigation-extraction method (Ross, 1992).

\subsection{Site description of field experiment}

This research was conducted at the Luhe Agricultural Station $\left(118^{\circ} 38^{\prime} 342^{\prime \prime}\right.$ E, $32^{\circ} 29^{\prime} 118^{\prime \prime}$ N) of the Jiangsu Academy of Agricultural Sciences, Jiangsu Province, China. The soil type was alluvial. The chemical characteristics of the soil were as follows: organic matter of $16.10 \mathrm{~g} \mathrm{~kg}^{-1}$ soil, alkaline hydrolysis $\mathrm{N}$ of $151.19 \mathrm{mg} \mathrm{kg}^{-1}$ soil, Olsen-P of $10.56 \mathrm{mg} \mathrm{kg}^{-1}$ soil, available $\mathrm{K}$ of $126.00 \mathrm{mg} \mathrm{kg}^{-1}$ soil, and $\mathrm{pH} 6.68$.

\subsection{Experimental design of field experiment}

Four fertilizer treatments were arranged in a randomized complete block design with four replications. Each plot was $5.00 \mathrm{~m} \times 4.00 \mathrm{~m}$ with a buffer zone of $0.50 \mathrm{~m}$ between each plot. There were four treatments as follows: no urea control (control, NA), urea (NB), PGAU1 (NC), and reduced $15.00 \%$ PGAU1 application (ND). Urea was the $\mathrm{N}$ source and broadcasted at the rate of $225.00 \mathrm{~kg} \mathrm{ha}^{-1} \mathrm{~N}$. Superphosphate was the $\mathrm{P}$ source and broadcasted at the rate of $90.00 \mathrm{~kg} \mathrm{ha}^{-1} \mathrm{P}_{2} \mathrm{O}_{5}$. Potassium sulfate was the $\mathrm{K}$ source and applied at the rate of $90.00 \mathrm{~kg} \mathrm{ha}^{-1}$ $\mathrm{K}_{2} \mathrm{O}$. PGAU1 was urea mixed with purified $\gamma$-PGA. The addition level of $\gamma$-PGA in PGAU1 was $0.10 \%$.

\subsection{Plant sampling and analysis of field experiment}

At physiological maturity, plants within $1 \mathrm{~m}^{2}$ of each plot were manually cut at ground level to measure dry matter and total N. Plant samples were digested by the Kjeldahl procedure and analyzed for total $\mathrm{N}$ by routine methods (Chapman and Pratt, 1961).At maturity, the grain yield and yield components, including the number of effective tiller, plant height, seeds per spike, and 1000-seed weight, were determined.

\subsection{Statistical analysis}

ANOVA was used to test the difference in each parameter among different treatments. Statistical analysis was performed by one-way ANOVA followed by Duncan's test $(p<0.05)$. Statistical analyses of all data were conducted using SPSS17.0. 
Table 1. Evaluations of wheat growth under the various treatments in the pot experiment

\begin{tabular}{ccccc}
\hline Treatments & $\begin{array}{c}\text { Spike number } \\
\text { per pot }\end{array}$ & $\begin{array}{c}1000 \text {-seed weight } \\
(\mathrm{g})\end{array}$ & $\begin{array}{c}\text { Seeds number per spike } \\
\text { na }\end{array}$ & $\begin{array}{c}\text { Total seeds weight per pot } \\
(\mathrm{g})\end{array}$ \\
\hline $\mathrm{nb}$ & $12.50 \pm 1.00^{\mathrm{b}}$ & $26.49 \pm 1.95^{\mathrm{b}}$ & $18.05 \pm 0.75^{\mathrm{c}}$ & $4.06 \pm 0.76^{\mathrm{c}}$ \\
$\mathrm{nc}$ & $13.50 \pm 0.58^{\mathrm{a}}$ & $28.51 \pm 0.87^{\mathrm{a}}$ & $25.30 \pm 0.30^{\mathrm{a}}$ & $8.79 \pm 0.61^{\mathrm{b}}$ \\
nd & $13.75 \pm 0.96^{\mathrm{a}}$ & $28.36 \pm 0.63^{\mathrm{a}}$ & $25.07 \pm 0.67^{\mathrm{ab}}$ & $9.73 \pm 0.27^{\mathrm{a}}$ \\
ne & $13.00 \pm 0.82^{\mathrm{a}}$ & $28.24 \pm 0.69^{\mathrm{a}}$ & $24.37 \pm 0.56^{\mathrm{b}}$ & $9.77 \pm 0.41^{\mathrm{a}}$ \\
nf & $13.00 \pm 1.15^{\mathrm{a}}$ & $28.15 \pm 0.85^{\mathrm{a}}$ & $24.52 \pm 0.54^{\mathrm{ab}}$ & $8.95 \pm 0.28^{\mathrm{b}}$ \\
\hline
\end{tabular}

na, no urea control; nb, urea; nc, PGAU1; nd, PGAU2; ne, reduced 15.00\% PGAU1 application; nf, reduced 15.00\% PGAU2 application. Values are means $\pm \mathrm{SD}(\mathrm{n}=4)$. The statistical analysis was performed by Duncan's test (at level $p<0.05)$. Means in the same column and with different letters are statistically different.

Table 2. Evaluations of wheat growth under the various treatments in the field experiment

\begin{tabular}{ccccc}
\hline Treatments & $\begin{array}{c}\text { Spike number } \\
\left(10^{4} / \mathrm{ha}\right)\end{array}$ & $\begin{array}{c}1000 \text {-seed weight } \\
(\mathrm{g})\end{array}$ & Seeds number per spike & $\begin{array}{c}\text { Yield } \\
(\mathrm{kg} / \mathrm{ha})\end{array}$ \\
\hline NA & $204.22 \pm 4.55^{\mathrm{c}}$ & $39.17 \pm 0.74^{\mathrm{b}}$ & $39.09 \pm 1.57^{\mathrm{c}}$ & $4649.86 \pm 92.30^{\mathrm{c}}$ \\
NB & $410.13 \pm 8.21^{\mathrm{b}}$ & $41.09 \pm 1.14^{\mathrm{a}}$ & $41.21 \pm 0.57^{\mathrm{b}}$ & $6938.05 \pm 43.64^{\mathrm{b}}$ \\
NC & $420.78 \pm 7.83^{\mathrm{a}}$ & $41.19 \pm 0.76^{\mathrm{a}}$ & $42.94 \pm 0.85^{\mathrm{a}}$ & $7435.69 \pm 55.91^{\mathrm{a}}$ \\
ND & $411.37 \pm 9.62^{\mathrm{ab}^{\mathrm{b}}}$ & $41.10 \pm 0.83^{\mathrm{a}}$ & $41.26 \pm 0.50^{\mathrm{b}}$ & $6973.26 \pm 49.20^{\mathrm{b}}$ \\
\hline
\end{tabular}

NA, no urea control; NB, urea; NC, PGAU1; ND, reduced $15.00 \%$ PGAU1 application. Values are means \pm SD ( $=4$ ). The statistical analysis was performed by Duncan's test (at level $p<0.05$ ). Means in the same column and with different letters are statistically different.

\section{Results and Discussion}

3.1. Spike number, spike dry weight, 1000-seed weight, and grain yield

In the pot experiment, $\gamma$-PGA application at maturity in all treatments resulted in increased spike number per pot, 1000-seed weight, seed number per spike, and total seed weight per pot (Table 1). The seed number per spike and total seed weight per pot significantly increased with the application of $\gamma$-PGA. The highest crop yield of PGAU2-treated plants significantly increased by $11.15 \%$, i.e., from $8.79 \pm 0.61 \mathrm{~g} \mathrm{pot}^{-1}$ in the urea treatment to $9.77 \pm 0.41 \mathrm{~g} \mathrm{pot}^{-1}$ in the PGAU2 treatment. With $15.00 \%$ decreased nitrogen fertilizer application, the grain yield increased by $1.82 \%-2.05 \%$ after $\gamma$-PGA application compared with treatment with urea only.

In the field experiment, similar results were observed after $\gamma$-PGA application (Table 2). Compared with treatment NB, plants treated with $\gamma$-PGA in all treatments showed a significant increase in the spike number, seed number per spike, and yield of winter wheat. PGAU1 significantly increased the spike number, seed number per spike, and yields of wheat by $2.60 \%, 4.20 \%$, and 
$7.17 \%$, respectively, compared with those in treatment NB. With $15.00 \%$ decreased PGAU1 application, the crop yield increased by $0.51 \%$ compared with that in treatment NB.

Tables 1 and 2 showed that seed yields of wheat were improved significantly after application of $\gamma$-PGA when nitrogen contents were at a normal level. After the nitrogen contents were decreased by $15 \%$, seed yields were no significantly differences compared with urea treatments.

\subsection{Total $N$ accumulation and $N$ recovery efficiency}

The pot experiment results presented in Table 3 indicate that dry matter production, grain concentration of $\mathrm{N}$, and total $\mathrm{N}$ accumulation were significantly affected by $\gamma$-PGA in all treatments. The straw production, grain production, and grain $\mathrm{N}$ concentration significantly from increased $9.38 \%-9.58 \%, 11.07 \%-11.53 \%$, and $5.35 \%-6.79 \%$, respectively, after $\gamma$-PGA application under the same level of $\mathrm{N}$ treatments. The application of $\gamma$-PGA in all treatments increased the $\mathrm{N}$ recovery efficiency by $11.81 \%-14.00 \%$ compared with that treatment $\mathrm{nb}$. The $\mathrm{N}$ recovery efficiency was also obviously higher with $127.50 \mathrm{mg}$ pot $^{-1} \mathrm{~N}$ than 150.00 mg $\operatorname{pot}^{-1} \mathrm{~N}$ after $\gamma$-PGA application.

In the field experiment, similar trends were observed after $\gamma$-PGA application (Table 4). Compared with treatment $\mathrm{NB}$, plants treated with $\gamma$-PGA showed a significantly increase in dry matter production, concentration of $\mathrm{N}$, and total $\mathrm{N}$ accumulation. PGAU1 significantly increased the straw production, grain production, and grain $\mathrm{N}$ concentration by $2.50 \%, 7.17 \%$, and $7.14 \%$, respectively, compared with treatment NB. The application of $\gamma$-PGA in all treatments increased the $\mathrm{N}$ recovery efficiency by $11.30 \%-11.38 \%$ compared with that in treatment NB. In general, $\gamma$-PGA application leads to significantly increased dry matter production and $\mathrm{N}$ concentration of wheat crop. Tables 3 and 4 show that the $\mathrm{N}$ use efficiency can be significantly increased by $\gamma$-PGA application. Similarly, N use efficiency was obviously higher in low $\mathrm{N}$ condition than in high $\mathrm{N}$ condition after $\gamma$-PGA application in both pot and field experiments. Therefore, $\gamma$-PGA can improve the growth of wheat and increase nutrient utilization, especially at relatively low nutrient levels.

\subsection{Total protein and starch}

$\gamma$-PGA application in all treatments resulted in obviously increased total protein concentration and starch. The total protein of wheat grain significantly increased from $3.88 \%$ to $6.75 \%$ with the application of $\gamma$-PGA compared with treatment nb in the pot experiment (Figure 1(a)). The total protein in plants treated with $\gamma$-PGA in the field experiment increased from $4.99 \%-7.14 \%$ compared with treatment NB (Figure 1(b)). The starch content of wheat grain increased from $0.11 \%-1.95 \%$ after $\gamma$-PGA application compared with treatment $\mathrm{nb}$ in the pot experiment (Figure 1(c)). Starch treated with PGAU1 in the field experiment increased by $0.28 \%$ compared with treatment NB (Figure 1(d)).

\subsection{Soil $\mathrm{NH}_{4}^{+}-\mathrm{N}, \mathrm{NO}_{3}^{-}-\mathrm{N}$, and $\mathrm{SMBN}$}

With the growth of wheat, ammonium $\mathrm{N}$ and nitrate $\mathrm{N}$ in the control decreased (Figure 2). In all treatments, the levels of ammonium $\mathrm{N}$ and nitrate $\mathrm{N}$ tended to be highest at the tillering stage, and then gradually decreased to a minimum in the maturity stage after the gradual increase from jointing stage. The levels of ammonium $\mathrm{N}$ treated with $\gamma$-PGA were higher than that of treatment nb throughout the entire growth period of wheat in the pot experiment. The levels of ammonium $\mathrm{N}$ with applied $\gamma$-PGA were $1.63-1.72 \mathrm{mg} \mathrm{kg}^{-1}$ higher than treatment $\mathrm{nb}$ under the same $\mathrm{N}$ level at the tillering stage, which was the maximum difference for the entire growth stage. The levels of nitrate $\mathrm{N}$ treated with $\gamma$-PGA were higher than treatment $\mathrm{nb}$ during the entire growth period of wheat except at the tillering stage. Under the same level of $\mathrm{N}$ conditions, the levels of nitrate $\mathrm{N}$ with the application of $\gamma$-PGA decreased by $1.06-1.08 \mathrm{mg} \mathrm{kg}^{-1}$ compared with treatment $\mathrm{nb}$ at the tillering stage. 
Table 3. Effects of $\gamma$-PGA on nitrogen use efficiency of wheat in the pot experiment

\begin{tabular}{|c|c|c|c|c|c|c|c|}
\hline \multirow[t]{2}{*}{ Treatments } & \multirow{2}{*}{$\begin{array}{c}\mathrm{N} \\
\text { application } \\
\text { ratio } \\
\text { (mg/pot) }\end{array}$} & \multicolumn{2}{|c|}{$\begin{array}{l}\text { Dry matter production } \\
(\mathrm{g})\end{array}$} & \multicolumn{2}{|c|}{$\begin{array}{c}\text { Concentration of N } \\
(\mathrm{g} / \mathrm{kg})\end{array}$} & \multirow[t]{2}{*}{$\begin{array}{c}\text { TNA } \\
\text { (mg/pot) }\end{array}$} & \multirow{2}{*}{$\begin{array}{l}\text { NRE } \\
(\%)\end{array}$} \\
\hline & & straw & grain & straw & grain & & \\
\hline na & 0.00 & $13.06 \pm 0.60^{c}$ & $4.06 \pm 0.76^{\mathrm{c}}$ & $4.92 \pm 0.58^{\mathrm{a}}$ & $18.54 \pm 0.77^{c}$ & $139.21 \pm 7.68^{\mathrm{c}}$ & - \\
\hline $\mathrm{nb}$ & 150.00 & $24.64 \pm 0.96^{\mathrm{b}}$ & $8.76 \pm 0.61^{\mathrm{b}}$ & $5.46 \pm 0.47^{\mathrm{a}}$ & $19.45 \pm 0.37^{\mathrm{b}}$ & $305.29 \pm 15.96^{\mathrm{b}}$ & 44.29 \\
\hline $\mathrm{nc}$ & 150.00 & $26.95 \pm 1.26^{\mathrm{a}}$ & $9.73 \pm 0.27^{\mathrm{a}}$ & $5.57 \pm 0.38^{\mathrm{a}}$ & $20.49 \pm 0.34^{\mathrm{a}}$ & $349.60 \pm 19.71^{\mathrm{a}}$ & 56.10 \\
\hline nd & 150.00 & $27.00 \pm 0.87^{\mathrm{a}}$ & $9.77 \pm 0.41^{\mathrm{a}}$ & $5.60 \pm 0.33^{\mathrm{a}}$ & $20.77 \pm 0.58^{\mathrm{a}}$ & $354.12 \pm 21.06^{\mathrm{a}}$ & 57.31 \\
\hline ne & 127.50 & $24.65 \pm 0.74^{\mathrm{ab}}$ & $8.95 \pm 0.28^{b}$ & $5.51 \pm 0.34^{\mathrm{a}}$ & $20.21 \pm 0.57^{\mathrm{ab}}$ & $322.02 \pm 9.01^{\mathrm{b}}$ & 57.35 \\
\hline $\mathrm{nf}$ & 127.50 & $24.79 \pm 0.79^{\mathrm{ab}}$ & $8.97 \pm 0.39^{\mathrm{ab}}$ & $5.52 \pm 0.35^{\mathrm{a}}$ & $20.33 \pm 0.41^{\mathrm{a}}$ & $325.01 \pm 7.39^{\mathrm{b}}$ & 58.29 \\
\hline
\end{tabular}

na, no urea control; nb, urea; nc, PGAU1; nd, PGAU2; ne, reduced 15.00\% PGAU1 application; nf, reduced 15.00\% PGAU2 application. Values are means $\pm \mathrm{SD}(\mathrm{n}=4)$. The statistical analysis was performed by Duncan's test (at level $p<0.05)$. Means in the same column and with different letters are statistically different. TNA: total N accumulation; NRE: N recovery efficiency.

Table 4. Effects of $\gamma$-PGA on nitrogen recovery efficiency of wheat in the field experiment

\begin{tabular}{cccccccc}
\hline & $\begin{array}{c}\mathrm{N} \\
\text { application } \\
\text { ratio } \\
\text { Treatments }\end{array}$ & \multicolumn{2}{c}{$\begin{array}{c}\text { Dry matter production } \\
(\mathrm{kg})\end{array}$} & \multicolumn{2}{c}{$\begin{array}{c}\text { Concentration of } \mathrm{N} \\
(\mathrm{g} / \mathrm{kg})\end{array}$} & $\begin{array}{c}\text { TNA } \\
(\mathrm{kg} / \mathrm{ha})\end{array}$ & $\begin{array}{c}\text { NRE } \\
(\%)\end{array}$ \\
\cline { 2 - 6 } & & straw & grain & straw & grain & \\
\hline NA & 0.00 & $5768.18 \pm 76.85^{\mathrm{c}}$ & $4649.86 \pm 92.30^{\mathrm{c}}$ & $5.33 \pm 0.29^{\mathrm{b}}$ & $20.11 \pm 0.47^{\mathrm{c}}$ & $124.26 \pm 3.83^{\mathrm{d}}$ \\
NB & 225.00 & $8262.78 \pm 40.18^{\mathrm{b}}$ & $6938.05 \pm 43.64^{\mathrm{b}}$ & $5.76 \pm 0.21^{\mathrm{a}}$ & $21.86 \pm 0.30^{\mathrm{b}}$ & $199.22 \pm 1.04^{\mathrm{c}}$ & 33.32 \\
NC & 225.00 & $8469.10 \pm 88.87^{\mathrm{a}}$ & $7435.69 \pm 55.91^{\mathrm{a}}$ & $5.97 \pm 0.18^{\mathrm{a}}$ & $23.42 \pm 0.63^{\mathrm{a}}$ & $224.65 \pm 5.50^{\mathrm{a}}$ & 44.62 \\
ND & 191.25 & $8345.25 \pm 95.57^{\mathrm{b}}$ & $6973.26 \pm 49.20^{\mathrm{b}}$ & $5.96 \pm 0.18^{\mathrm{a}}$ & $22.95 \pm 0.53^{\mathrm{a}}$ & $209.74 \pm 3.24^{\mathrm{b}}$ & 44.70 \\
\hline
\end{tabular}

NA, no urea control; NB, urea; NC, PGAU1; ND, reduced 15.00\% PGAU1 application. Values are means \pm SD ( $n=4)$. The statistical analysis was performed by Duncan's test (at level $p<0.05$ ). Means in the same column and with different letters are statiswtically different. TNA: total $\mathrm{N}$ accumulation; NRE: $\mathrm{N}$ recovery efficiency.

However, the levels of nitrate $\mathrm{N}$ after $\gamma$-PGA application increased by $1.56-1.60 \mathrm{mg} \mathrm{kg}^{-1}$ compared with treatment $\mathrm{nb}$ at the booting stage, which was the maximum difference for the entire growth stage. SBMN treated with $\gamma$-PGA increased from tillering and reached its maximum at the jointing stage, dropped to a minimum at the booting stage, and then continuously increased until maturity. However, SMBN in the control and treatment $\mathrm{nb}$ treatments dropped from tillering and reached its minimum at the jointing stage, increased in the anthesis stage, and then continuously dropped until maturity (Figure 2(c)). SMBN after $\gamma$-PGA application increased to $3.70-7.91 \mathrm{mg} \mathrm{kg}^{-1}$ and increased by $17.35 \%-37.08 \%$ at the tillering stage, and then further increased to $9.65-13.85$ $\mathrm{mg} \mathrm{kg}{ }^{-1}$ and increased by $49.03 \%-70.38 \%$ compared with treatment $\mathrm{nb}$ at the jointing stage. However, the amount of SMBN after $\gamma$-PGA application decreased to 0.61-1.92 mg kg-1 and decreased by $2.73 \%-8.58 \%$ compared with control at the booting stage except in the treatment with reduced $15.00 \%$ PGAU1 application. More mineral N in soil was immobilized by the microbes after $\gamma$-PGA application at the early growth stage of wheat, and the immobilized $\mathrm{N}$ was gradually released at the late jointing and booting stages. 

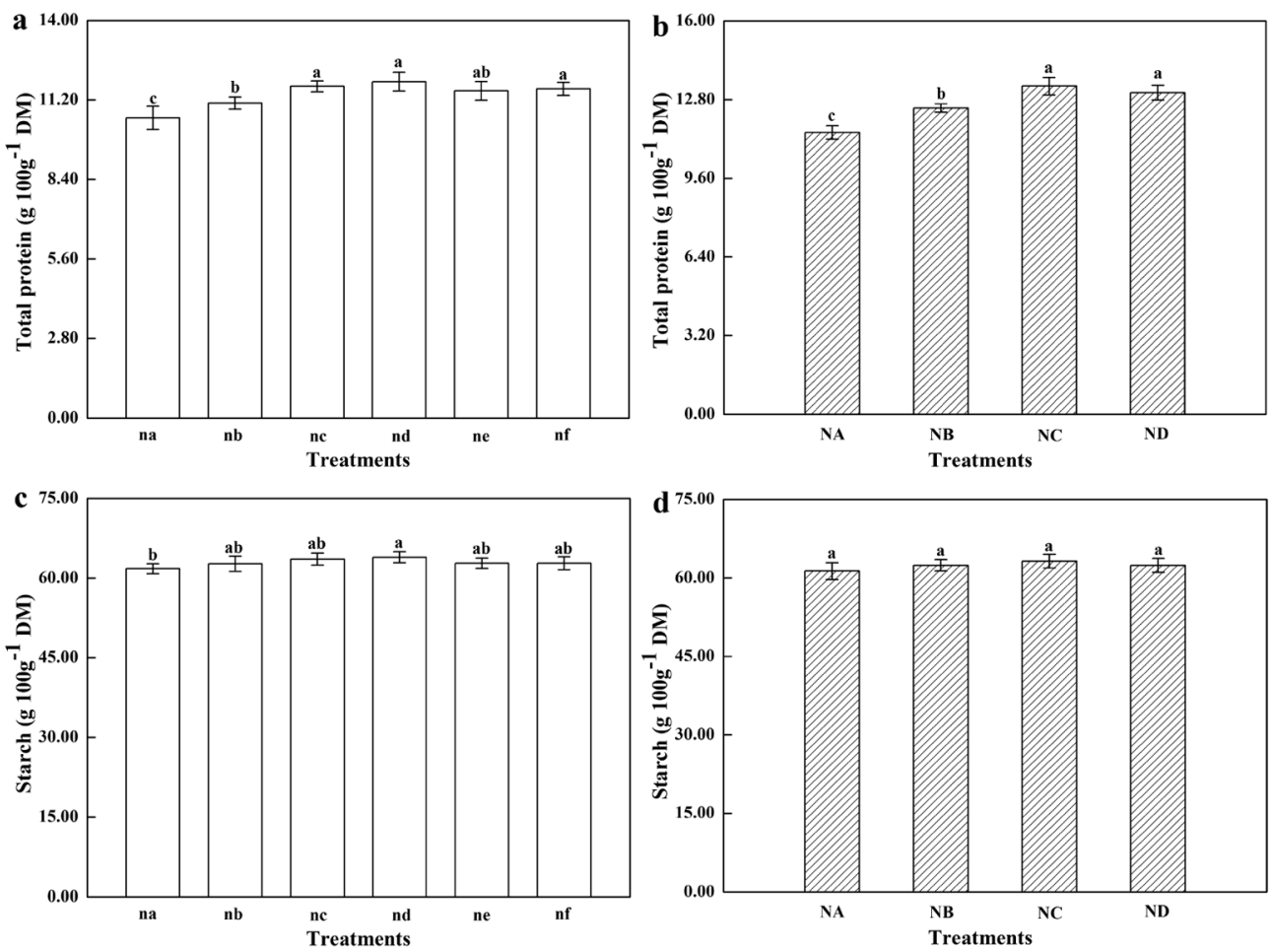

Figure 1. (a) Total protein in pot experiment, (b) Total protein in field experiment, (c) Starch in pot experiment and (d) Starch in field experiment treated with $\gamma$-PGA application. Treatments in the pot experiment: na, no urea control; nb, urea; nc, PGAU1; nd, PGAU2; ne, reduced $15.00 \%$ PGAU1 application; nf, reduced 15.00\% PGAU2 application. Treatments in the field experiment: NA, no urea control; NB, urea; NC, PGAU1; ND, reduced $15.00 \%$ PGAU1 application. Values are means \pm SD $(\mathrm{n}=4)$. The statistical analysis was performed by Duncan's test (at level $p<0.05$ ). Means in the same column and with different letters are statistically different.

\subsection{Soil enzyme}

The soil urease activity increased from tillering and reached its maximum at the jointing stage, and then dropped to a minimum at the maturity stage (Figure 3). Urease activity varied between 0.95 and $1.60 \mathrm{mg} \mathrm{NH}_{4}^{+}-\mathrm{N}$ per gram soil. Soil urease activity after $\gamma$-PGA application increased by $7.14 \%-14.2 \%$ compared with treatment $\mathrm{nb}$ at the jointing stage. Sucrase and catalase activities continuously increased from the tillering stage, reached its maximum at the booting stage, and then dropped at the maturity stage. The lowest sucrase and catalase activities were both observed at the jointing stage. In soils treated with $\gamma$-PGA, the sucrase activity increased by $8.82 \%$ $23.47 \%$ at the booting stage. The catalase activity in soils treated after $\gamma$-PGA application increased by $9.43 \%-18.87 \%$ compared with treatment $\mathrm{nb}$ at the tillering stage. 

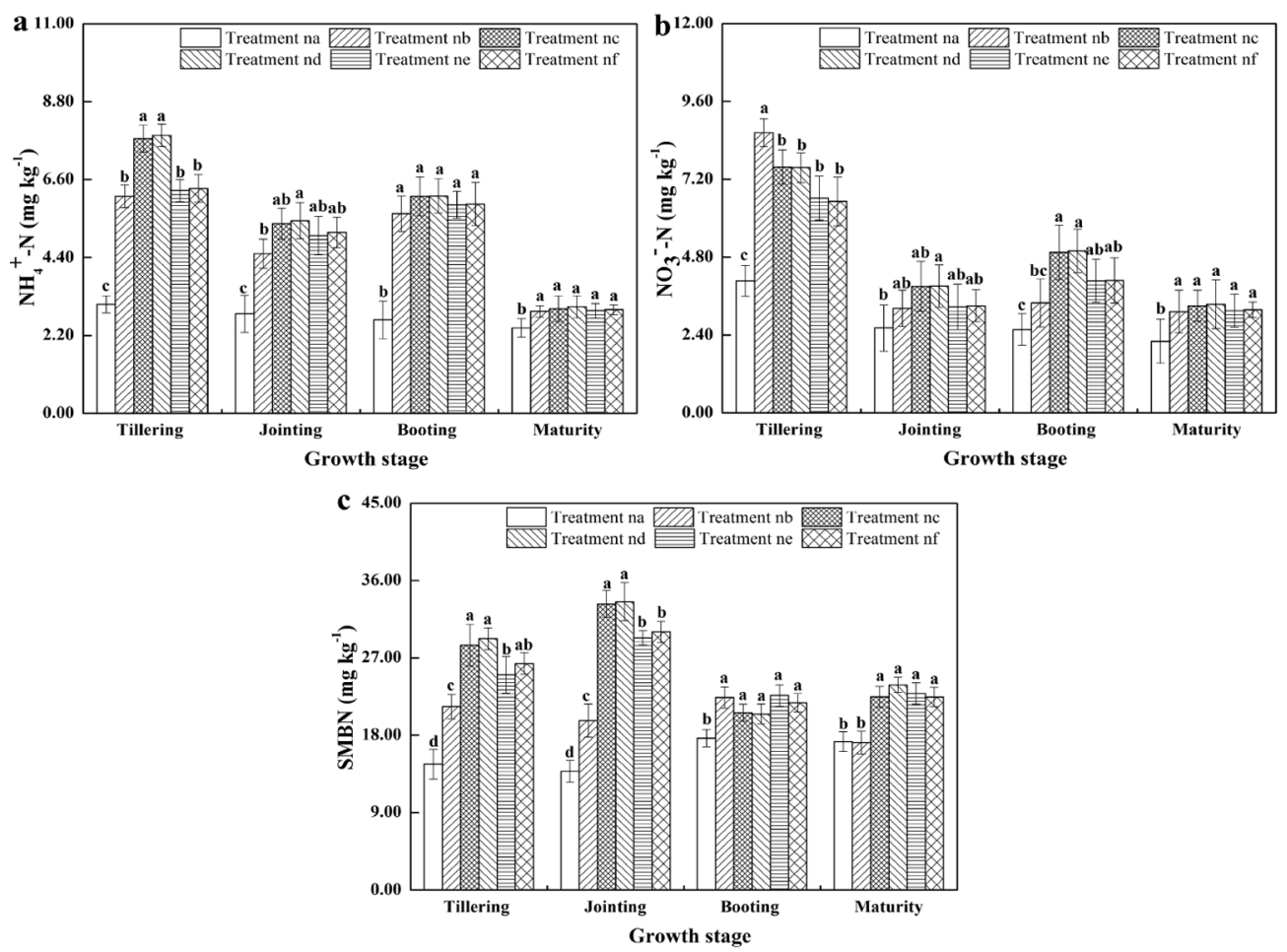

Figure 2. Change of $\mathrm{NH}_{4}^{+}-\mathrm{N}(\mathrm{a}), \mathrm{NO}_{3}^{-}-\mathrm{N}(\mathrm{b})$ and $\mathrm{SMBN}(\mathrm{c})$ in the wheat soil in the pot experiment. Treatments in the pot experiment: na, no urea control; nb, urea; nc, PGAU1; nd, PGAU2; ne, reduced 15.00\% PGAU1 application; nf, reduced $15.00 \%$ PGAU2 application. Treatments in the field experiment: NA, no urea control; NB, urea; NC, PGAU1; $\mathrm{ND}$, reduced $15.00 \%$ PGAU1 application. Values are means \pm SD $(n=4)$. The statistical analysis was performed by Duncan's test (at level $p<0.05$ ). Means in the same column and with different letters are statistically different.

The significant increase in the yield after $\gamma$-PGA application can be due to the changes induced by $\gamma$-PGA in the soil biological properties (including soil enzyme activities and biomass size) (Liu et al., 2013). More mineral $\mathrm{N}$ in soil was immobilized by the microbes after $\gamma$-PGA application at the early growth stage of wheat, and the immobilized $\mathrm{N}$ was gradually released at the late jointing and booting stages. The size of the microbial biomass $\mathrm{N}$ pool, which plays a key role in the $\mathrm{N}$ cycle (Bristow and Jarvis, 1991; Lovell and Jarvis, 1996), was significantly affected by $\gamma$-PGA application (Figure 2(c)). The amount of $\mathrm{N}$ lost with $\gamma$-PGA treatment is lower than that in the no- $\gamma$ PGA control. The amount of soil $\mathrm{N}$ available for plant growth may be increased by $\gamma$-PGA application. Some other possible reasons are as follows. First, previous research showed that the dry weight of shoots and roots, as well as the root-to-shoot ratio of cucumber seedlings can be increased by $\gamma$-PGA application (Wang et al., 2008). Physiologically, differences among $\mathrm{N}$ acquisition can be attributed to the root size (Marschener, 1998; Kim et al., 2001; Liu et al., 2009), and wheat root can be stimulated by providing $\gamma$-PGA both in the pot and field experiments. 

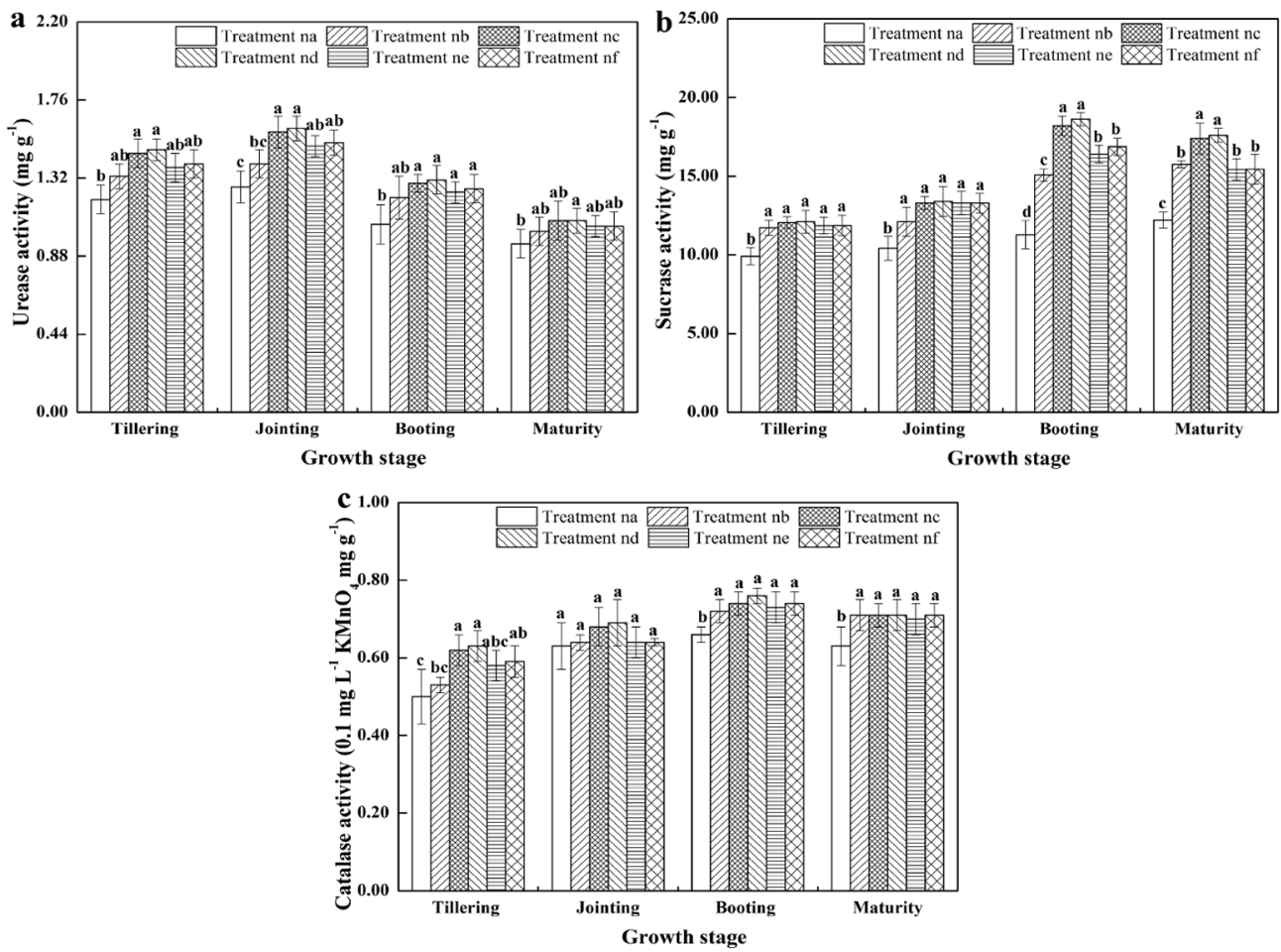

Figure 3. Urease activity (a), Sucrase activity (b) and Catalase activity (c) in the soil treated with $\gamma$-PGA application in pot experiment. Treatments in the pot experiment: na, no urea control; nb, urea; nc, PGAU1; nd, PGAU2; ne, reduced $15.00 \%$ PGAU1 application; nf, reduced $15.00 \%$ PGAU2 application. Treatments in the field experiment: NA, no urea control; NB, urea; NC, PGAU1; ND, reduced $15.00 \%$ PGAU1 application. Values are means \pm SD $(\mathrm{n}=4)$. The statistical analysis was performed by Duncan's test (at level $p<0.05)$. Means in the same column and with different letters are statistically different.

Thus, the the roots of plants may have a higher capacity for nutrient uptake. Second, the assimilation of $\mathrm{N}$ plays an important role in plant growth and development. The first step of the incorporation of inorganic $\mathrm{N}$ into organic nitrogenous compounds via the glutamine synthetase/glutamate synthase assimilatory pathway is likely to be a major checkpoint for controlling the assimilation of plant $\mathrm{N}$ (Cai et al., 2009) The improvement in the yield and $\mathrm{N}$ uptake of wheat after $\gamma$-PGA application may be due to the increase in the activities of glutamine synthetase and glutamate synthase by $\gamma$-PGA. Third, $\gamma$-PGA possibly affects the rates of ammonium ion uptake in plant roots. The mechanism by which plants are stimulated by $\gamma$-PGA requires further study. To study the effect of the form of added $\gamma$-PGA on wheat productivity and soil microbes, two fertilizer forms of $\gamma$-PGA were designed in the pot experiment, namely, PGAU1 and PGAU2. PGAU1 was urea mixed with purified $\gamma$-PGA. PGAU2 was urea coated with purified $\gamma$-PGA. The addition level of $\gamma$-PGA in the two fertilizers was the same. 
PGAU2 was found to work better than PGAU1, which can be attributed to $\gamma$-PGA being a polyanionic biopolymer (Lin et al., 2006). Urea coated with purified $\gamma$-PGA highly adsorbs ammonium $\mathrm{N}$, which can reduce $\mathrm{N}$ loss.

These effects can be attributed to the fertilizer synergist activity of $\gamma$-PGA, which may contribute to decreased excessive chemical fertilizer use and environmental pollution.

\section{Conclusions}

$\gamma$-PGA can significantly increase the number of tillers, seed number per spike, and yield of winter wheat, as well as enhance the amount of soil microbial $\mathrm{N}$ at the early growth stage. The $\mathrm{N}$ immobilized by soil microbes can be mineralized during the late growth stage of wheat and increase the soil available N. The activities of urease, sucrose, and catalase in the soil increased after $\gamma$-PGA application. $\gamma$-PGA can be used as a fertilizer synergist to decrease excessive chemical fertilizer use and environmental pollution.

\section{Acknowledgements}

This work was funded by the National Basic Research Program of China (973) (No. 2013CB733600), the National Basic Research Program of China (973) (No. 2009CB724799), Program for Changjiang Scholars and Innovative Research Team in University (IRT1066), the National Nature Science Foundation of China (No. 21006050), Jiangsu Provincial basic research program (Natural Science Foundation) (No. SBK200910195), the National Key Technology R\&D Program (2011BAD23B04),Nanjing Innovation Fund for Technology Based Firms (2012062), and Graduate Student innovation Project of Jiangsu Province (No. CXZZ13_0463)

\section{References}

Ashiuchi, M. 2010. Occurrence and Biosynthetic Mechanism of Poly-Gamma-Glutamic Acid, in Hamano, Y. (eds.): Amino-Acid Homopolymers Occurring in Nature, Department of Bioscience, Fukui Prefectural University, Janpan. pp. 7793.

Bremner, J.M. 1995. Recent research on problems in the use of urea as a nitrogen fertilizer. Fert. Res. $42,321-329$.

Bristow, A.W., Jarvis, S.C. 1991. Effects of grazing and nitrogen fertiliser on the soil microbial biomass under permanent pasture. Soil Biol. Biochem. 54, 9-21.

Cai, H.M., Zhou, Y., Xiao, J.H., Li, X.H., Zhang, Q.F., Lian, X.M. 2009. Overexpressed glutamine synthetase gene modifies nitrogen metabolism and abiotic stress responses in rice. Plant Cell Rep. 28, 527-537.

Chapman, H.D., Pratt, P.F. 1961. Method for Analysis of Soil, Plants and Waters, USA: Division of Agriculture Science. University of California: Riverside. CA: 1188.

Chen, X., Chen, S.W., Sun, M., Yu, Z.N. 2005. High yield of poly- $\gamma$-glutamic acid from Bacillus subtilis by solid-state fermentation using swine manure as the basis of a solid substrate. Bioresour. Technol. $96,1872-1879$.

Dalal, R.C., 1998. Soil microbial biomass - what do the numbers really mean? Aust. J. Exp. Agric. 38, 649-665.

Datta, S.P., Rattan, R.K., Chandra, S. 2010. Labile soil organic carbon, soil fertility, and crop productivity as influenced by manure and mineral fertilizers in the tropics. J. Plant Nutr. Soil Sci. 173, 715-726. 
Goulding, K.W.T. 2007. Nutrient management on farms, or 'you get out what you put in'. J. Sci. Food Agr. 87, 177-180.

Han, W.Y., Ma, L.F., Shi, Y.Z., Ruan, J.Y., Kemmitt, S.J. 2008. Nitrogen release dynamics and transformation of slow release fertiliser products and their effects on tea yield and quality. J. Sci. Food Agr. 88, 839-846.

Henriksen, A., Selmer-Olsen, A.R. 1970. Automatic methods for determining nitrate and nitrite in water and soil extracts. Analyst. 95, 514-518.

Iizumi, T., Masahiro, M., Kanji, N. 1998. A bioluminescence assay using Nitrosomonas europaea for rapid and sensitive detection of nitrification inhibitors. Appl. Environ. Microbiol. 64, 3656-3662.

Khalil, M.I., Gutser, R., Schmidhalter, U. 2009. Effects of urease and nitrification inhibitors added to urea on nitrous oxide emissions from a loess soil. J. Plant Nutr. Soil Sci. 172, 651-660.

Kim, H.Y., Lieffering, M., Miura, S., Kobayashi, K., Okada, M. 2001. Growth and nitrogen uptake of $\mathrm{CO} 2$-enriched rice under field conditions. New Phytol.150, 223-229.

King, W.E., Fister, R.P., Norris, S.J. 2011. U.S. Pat. 12862328, Regal Chemical Comp..

Koskan, L.P., Meah, A.R.Y., Sanders, J.L., Ross, R.J. 1998. U.S. Pat. 5783523, Donlar Corp..

Krom, M.D. 1980. Spectrophotometric determination of ammonia: a study of a modified Berthelot reaction using salicylate and dichloroisocyanurate. Analyst. 105, 305-316.

Lin, W.C., Yu, D.G., Yang, M.C. 2006. Blood compatibility of novel poly(gamma-glutamic acid)/polyvinyl alcohol hydrogels. Colloid. Surface. B. 47, 43-49.
Liu, C.H., Liu ,Y., Fan C., Kuang S.Z. 2013. The effects of composted pineapple residue return on soil properties and the growth and yield of pineapple. J. Soil Sci. Plant Nutr. DOI 10.4067/ S0718-95162013005000034.

Liu, J.X., Chen, F.J., Olokhnuud, C.L., Glass, A.D.M., Tong, Y.P., Zhang, F.S., Mi G.H. 2009. Root size and nitrogen-uptake activity in two maize (Zea mays) inbred lines differing in nitrogen-use efficiency. J. Plant Nutr. Soil Sci.172, 230-236.

Lovell, R.D., Jarvis, S.C. 1996. Effect of cattle dung on soil microbial biomass $\mathrm{C}$ and $\mathrm{N}$ in a permanent pasture soil. Soil Biol. Biochem. 28, 291-299.

Mahmoud, E.K., Abd EL-Kader, N.K. 2012. How the nitrogen fertilization dose affects the biochemical. J. Soil Sci. Plant Nutr. 12, 23-31.

Marschener, H. 1998. Role of root growth, arbuscular mycorrhiza, and root exudates for the efficiency in nutrient acquisition. Field Crops Res.56, 203-207.

Matson, P.A., Naylor, R., Ortiz-Monasterio, I. 1998. Integration of Environmental, Agronomic, and Economic Aspects of Fertilizer Management. Science. 280, 112-115.

Motavalli, PP., Kelling, K.A., Converse, J.C. 1989. First-year nutrient availability from injected dairy manure. J. Environ. Qual. 18, 180-185.

Ross, D.J. 1992. Influence of sieve mesh size on estimates of microbial carbon and nitrogen by fumigation extraction procedures in soils under pasture. Soil Biol. Biochem. 24, 343-350.

Shih, I.L., Van, Y.T. 2001. The production of poly- $(\gamma-$ glutamicacid) from microorganisms and its various applications. Bioresour. Technol. 79, 207-225. 
Thakur, A.K., Rath, S., Mandal, K.G. 2013. Differential responses of system of rice intensification (SRI) and conventional flooded-rice management methods to applications of nitrogen fertilizer. Plant Soil. 370, 59-71.

Tu, C., Ristaino, J.B., Hu, S.J. 2006. Soil microbial biomass and activity in organic tomato farming systems: Effects of organic inputs and straw mulching. Soil Biol. Biochem. 38, 247-255.

Ulrich, S., Tischer, S., Hofmann, B., Christen, O. 2010. Biological soil properties in a long-term tillage trial in Germany. J. Plant Nutr. Soil Sci. 173, 483-489.
Wang, Q.J., Chen, S.W., Zhang, J.B., Sun, M., Liu, Z.D, Yu, Z.N. 2008. Co-producing lipopeptides and poly-gamma-glutamic acid by solid-state fermentation of Bacillus subtilis using soybean and sweet potato residues and its bliocontrol and fertilizer synergistic effects. Bioresour. Technol. 99, 3318-3323.

Yang, Q., Wang, X., Shen, Y. 2013. Comparison of soil microbial community catabolic diversity between rhizosphere and bulk soil induced by tillage or residue retention. J. Soil Sci. Plant Nutr. DOI 10.4067/S0718-95162013005000017. 